\title{
Metabolite I of Protopanaxadiol-Type Saponins, an Axonal Regenerative Factor, Stimulates Teneurin-2 Linked by PI3-Kinase Cascade
}

\author{
Chihiro Tohda*,', Itsuki Hashimoto², Tomoharu Kuboyama ${ }^{2}$ and Katsuko Komatsu ${ }^{2,3}$ \\ 'Division of Biofunctional Evaluation, Research Center for Ethnomedicine, Institute of Natural Medicine, University of Toyama, Toyama, Japan; \\ ${ }^{2}$ Division of Pharmacognosy, Institute of Natural Medicine, University of Toyama, Toyama, Japan; ${ }^{3} 2$ I st Century COE Program, University of \\ Toyama, Toyama, Japan
}

\begin{abstract}
We previously showed that 20-O- $\beta$-D-glucopyranosyl-20(S)-protopanaxadiol (MI), a metabolite of protopanaxadiol-type ginseng saponins by intestinal bacteria had axonal extension activity in degenerated neurons, and improved memory disorder and synaptic loss induced by an active fragment of amyloid $\beta, A \beta(25-35)$. It is unknown how $\mathrm{Ml}$ shows these effects in neurons. To clarify the signal transduction mechanism of $\mathrm{Ml}$-induced axonal extension, phosphorylated proteins by $\mathrm{MI}$ stimulation were identified because most cellular signal pathways are regulated by phosphorylation/dephosphorylation. The combination of immunoprecipitation and MALDITOF-MS revealed that teneurin-2 and mPar3 were specifically phosphorylated by MI stimulation. Because mPar3 is known as an axonal specifying molecule and to be regulated by phosphatidylinositol 3-kinase (PI3-kinase), the involvement of teneurin-2 and PI3-kinase in the MI signal was studied. In teneurin-2-deficient cortical neurons, MI-induced axonal extension and PI3-kinase activation were significantly inhibited. In addition, treatment with PI3-kinase inhibitor also reduced MI-induced axonal extension. These results suggest that MI induces axonal outgrowth through the teneurin-2 - PI3-kinase cascade.

Neuropsychopharmacology (2006) 3 I, I I 58- I | 64. doi: I 0. I038/sj.npp. I 300943; published online 2 November 2005
\end{abstract}

Keywords: MI; teneurin-2; mPar3; axon; synapse; ginseng

\section{INTRODUCTION}

Ginseng, the root of Panax ginseng, is widely used as a tonic medicine throughout the world, and has also been found to be efficacious in the treatment of amnesia. We previously studied the neurite outgrowth activity of methanol extracts from seven ginseng drugs and 19 constituents isolated from Ye-Sanchi (rhizome of Panax vietnamensis HA et GRUSHV. var. fuscidiscus K.KOMATSU, S.ZHU \& S.Q.CAI) and Kouzichi (rhizome of P. japonicus C.A. MEYER var. major C.Y.WU et FENG) in human neuroblastoma SK-N-SH cells, and found that protopanaxadiol-type (ppd-type) saponins (ginsenoside $R b_{1}$, ginsenoside $R b_{3}$, notoginsenoside $R_{4}$ and notoginsenoside $\mathrm{Fa}$ ) were the active compounds (Tohda et al, 2002). Ppd-type saponins are known to be completely metabolized into 20-O- $\beta$-D-glucopyranosyl-20(S)-proto-

*Correspondence: Dr C Tohda, Research Center for Ethnomedicine, Institute of Natural Medicine, University of Toyama, 2630 Sugitani, Toyama 930-0194, Japan, Tel: +8I 76434 7646, Fax: +8I 76434 5068, E-mail: chihiro@ms.toyama-mpu.ac.jp

Received I June 2005; revised 30 August 2005; accepted 30 August 2005

Online publication: 15 September 2005 at http://www.acnp.org/ citations/Npp09| 505050353/default.pdf panaxadiol (M1) by intestinal bacteria when taken orally (Odani et al, 1983; Tawab et al, 2003). Our previous report showed that M1 had axonal extension activity in degenerated neurons, and ameliorated memory disorder and synaptic loss in an Alzheimer's mouse model induced by A $\beta$ (25-35) (Tohda et al, 2004).

M1 was also reported to have anticancer effect (Wakabayashi et al, 1998; Lee et al, 1999) in addition to axonal regeneration and antidementia effects. Binding molecules and the signal transduction mechanism of M1, however, is still unknown. Therefore, we aimed to identify the target molecules of M1, and designed an approach to detect phosphorylated proteins by M1 stimulation using immunoprecipitation and the matrix-associated laser desorption/ ionization-time of flight-mass spectrometry (MALDI-TOFMS). As a result, two interesting candidates were revealed. Teneurin-2 is a neuronal cell surface protein with one transmembrane domain. Putative functions of teneurin-2 may be recognizing and forming synapses, because teneurin-2 overexpression leads to the enlargement of filopodia and growth cones (Rubin et al, 1999), and teneurin-2 is expressed when axons find their targets (Rubin et al, 2002). Another candidate is mPar3, a key molecule for polarizing and axonal specifying signals in 
neurons, which is regulated by phosphatidylinositol 3kinase (PI3-kinase) (Shi et al, 2003). Therefore, it was investigated whether the M1 signal was related to teneurin-2 and PI3-kinase.

\section{METHODS}

\section{Materials}

M1 was enzymatically prepared from ginsenoside $\mathrm{Rd}$, and $800 \mathrm{mg}$ was dissolved in $60 \mathrm{ml}$ of $0.2 \mathrm{M}$ sodium dihydrogenphosphate buffer ( $\mathrm{pH} 4.0$ ), to which was gradually added $12 \mathrm{ml}$ ethanol, $2 \mathrm{~g}$ of naringinase (Sigma-Aldrich, St Louis, $\mathrm{MO}$ ), and $8 \mathrm{ml}$ toluene. After incubation at $40^{\circ} \mathrm{C}$ for 7 days, the mixture was extracted three times with $100 \mathrm{ml}$ ether and dehydrated by filtration over magnesium sulfate. After concentration under reduced pressure, the product was purified by column chromatography over silica gel to give $190.9 \mathrm{mg}$ of M1. The chemical structure of M1 was identified as follows: a white amorphous powder, ${ }^{1} \mathrm{H}-\mathrm{NMR}$ (pyridine$d 5)$ : signals for the aglycone moiety at $\delta 0.78-2.61,3.41(1 \mathrm{H}$, $\mathrm{m}, \mathrm{H}-3)$, and $5.24(1 \mathrm{H}, \mathrm{t}$-like, $\mathrm{H}-24)$. Signals for a glycosyl moiety at $\delta 3.84-4.45(6 \mathrm{H}, \mathrm{m}$, including a proton signal for $\mathrm{H}-12$ of the aglycone) and $5.15\left(1 \mathrm{H}, \mathrm{d}, J=7.5 \mathrm{~Hz}, \mathrm{H}-\mathrm{1}^{\prime}\right)$. LY294002 and A $\beta$ (25-35) were purchased from Biomol (Plymouth Meeting) and Sigma-Aldrich, respectively.

\section{Procedures}

Primary culture. Embryos were removed from pregnant Sprague-Dawley rats (Japan SLC, Shizuoka, Japan) at 17 or 18 days of gestation. The animals were handled in accordance with the Guide for Animal Experiments, Toyama Medical and Pharmaceutical University. The cortices were dissected, and the dura mater was removed. The tissue was chopped, the cells were dissociated, and plated onto eight-well chamber slides (BD Falcon, Bedford, MA) at a density of $1.0 \times 10^{5} \mathrm{cells} / \mathrm{cm}^{2}$ (Figures 1, 3-6), $7.35 \times 10^{4} \mathrm{cell} / \mathrm{cm}^{2}$ (Figure 7), or onto a $100-\mathrm{mm}$ diameter dish at a density of $8.8 \times 10^{4}$ cells $/ \mathrm{cm}^{2}$ (Figure 2) coated with poly-D-lysine $(5 \mu \mathrm{g} / \mathrm{ml})$, and grown at $37^{\circ} \mathrm{C}$ in a humidified atmosphere with $10 \% \mathrm{CO}_{2}$.

Analysis of neurite outgrowth. Rat cortical neurons were cultured for several days as shown in each figure. The cells were fixed with $4 \%$ paraformaldehyde and immunostained with a monoclonal antibody to phosphorylated NF-H (dilution 1:1000; Sternberger Monoclonals Inc., Lutherville, $\mathrm{MD}$ ) as an axonal marker, or with a monoclonal antibody to MAP2 (dilution 1:1000; Chemicon, Temecula, CA) as a dendritic marker as shown in our previous report (Tohda et al, 2004). Fluorescence images were captured using a fluorescence microscope (AX-80, Olympus, Tokyo, Japan) at $1709.4 \times 2273.5 \mu \mathrm{m}$, and $4-6$ images were captured per treatment. The lengths of neurites positive for phosphorylated NF-H or MAP2 were measured using an image analyzer (Scion Image, Scion, Frederick, MD) for each cell.

Analysis of phosphorylated Akt. The cells were fixed and double-immunostained with the combination of a polyclonal antibody to phosphorylated Akt (S473) (dilution
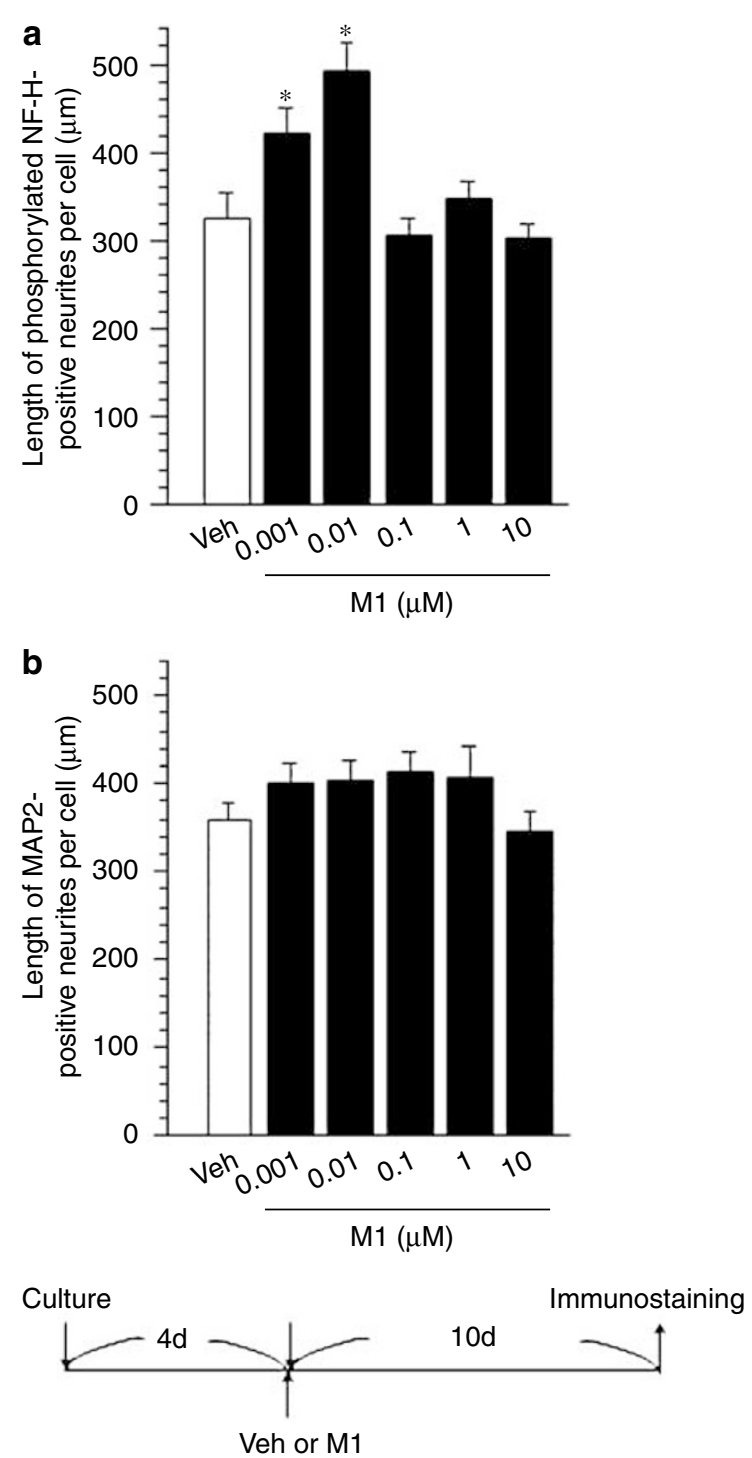

Figure I Effect of $\mathrm{MI}$ on the extension of axons and dendrites. $\mathrm{MI}$ $(0.001-10 \mu M)$ or a vehicle (Veh, 0.1\% DMSO) was added to rat cortical neurons 4 days after the start of the culture period. After 10 days, cells were fixed and immunostained for phosphorylated NF-H (a) and MAP2 (b). The lengths of neurites positive for phosphorylated NF-H or MAP2 per cell were measured. Values represent the means and SEM of 24-37 neurons. ${ }^{*} P<0.05$ when compared with Veh.

1:1000; R\&D Systems, Inc., Minneapolis) and a monoclonal antibody to phosphorylated NF-H (Sternberger Monoclonals Inc.), or with a polyclonal antibody to phosphorylated Akt and a monoclonal antibody to MAP2 (Chemicon). Alexa Fluor 488-conjugated goat anti-mouse IgG and Alexa Fluor 546-conjugated goat anti-rabbit IgG (dilution 1:200; Molecular Probes) were used as secondary antibodies. Fluorescence images were captured using a fluorescence microscope $(\mathrm{AX}-80)$ at $437 \times 328 \mu \mathrm{m}$, and four images were captured per treatment. The area of positive puncta to phosphorylated Akt on each axon or dendrite was measured using an image analyzer (ATTO densitograph, ATTO, Tokyo, Japan). The length of the axons and dendrites was measured with Scion Image software (Scion). 


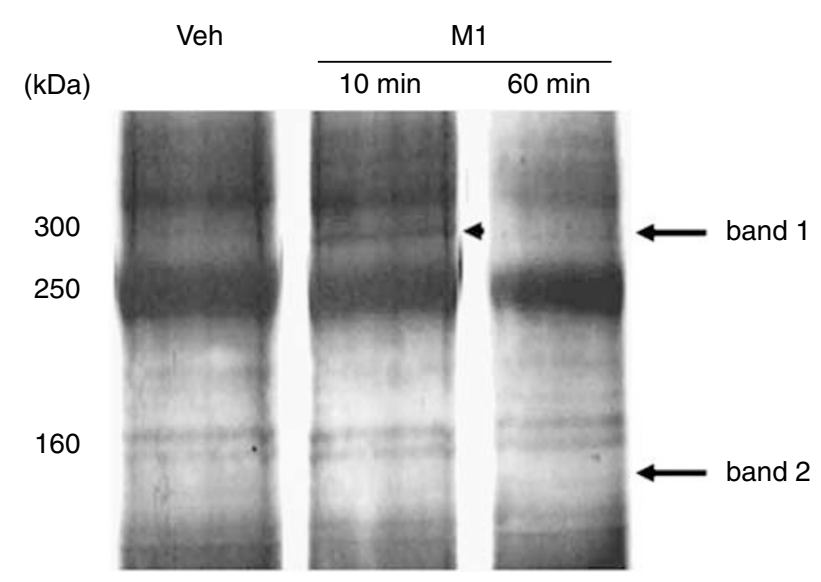

Figure 2 Phosphorylated proteins by $\mathrm{MI}$ stimulation. Rat cortical neurons were treated by $0.01 \mu \mathrm{M} M I$ or the vehicle (Veh, $0.1 \% \mathrm{DMSO}$ ), and after 10 and 60 min incubation, the reaction was stopped. Cell lysate was immunoprecipitated with antiphosphorylated tyrosine antibody. Precipitated samples were electrophoresed on SDS-PAGE, and silver stained. In a lane of MI-treated cells, a band of approximately $300 \mathrm{kDa}$ (band I) after 10-min stimulation, and a band of less than $160 \mathrm{kDa}$ (band 2) after 60-min stimulation were seen, which were hardly detected in the control lane (60 min after stimulation).

Immunoprecipitation. Cells were treated with drugs for 10 or $60 \mathrm{~min}$, and lysed with $1 \%$ Nonided-TNE buffer $(1 \%$ Nonided P40, $20 \mathrm{mM}$ Tris- $\mathrm{HCl}(\mathrm{pH} 7.4), 150 \mathrm{mM} \mathrm{NaCl}$, $2 \mathrm{mM}$ EDTA, $50 \mathrm{mM}$ NaF, $1 \mathrm{mM}$ PMSF, $10 \mu \mathrm{g} / \mathrm{ml}$ aprotinin, $10 \mu \mathrm{g} / \mathrm{ml}$ leupeptin) for $30 \mathrm{~min}$ on ice, and centrifuged at 10000 r.p.m. for $5 \mathrm{~min}$. Quantified proteins of the supernatant $(1.5 \mathrm{mg})$ were suspended in $0.2 \%$ Nonided-TNE buffer, and were added to protein $\mathrm{G}$ solution. After shaking for $1 \mathrm{~h}$ at $4^{\circ} \mathrm{C}$, samples were centrifuged at 5000 r.p.m. for $3 \mathrm{~min}$. Antiphosphorylated tyrosine monoclonal antibody (dilution 1:1000; Chemicon) was added to the supernatants. After incubation for $15 \mathrm{~h}$ at $4^{\circ} \mathrm{C}$, protein $\mathrm{G}$ solution was added, the solution further incubated for $1 \mathrm{~h}$ at $4{ }^{\circ} \mathrm{C}$, and centrifuged for $1 \mathrm{~min}$ at 5000 r.p.m. Precipitates were dissolved in $0.2 \%$ Nonided-TNE buffer, and centrifuged for $1 \mathrm{~min}$ at 5000 r.p.m. Final precipitates after three repeats of centrifugation were immunoprecipitated samples.

SDS-PAGE and silver staining. The immunoprecipitated sample and an equal volume of sample buffer (125 mM Tris$\mathrm{HCl}$ (pH 6.8), 4\% SDS, $10 \%$ sucrose, $10 \%$ 2-mercaptoethanol, $0.004 \%$ bromophenol blue) were mixed, and boiled for $3 \mathrm{~min}$. The $10 \%$ gels were run at $250 \mathrm{~V}$ for $2 \mathrm{~h}$ until the dye front reached the bottom of the gel. Silver staining of gels was performed as described in the manufacturer's procedures (Amersham Pharmacia Biotech Inc., Piscataway, NJ).

In gel digestion. Protein bands were excised from the gel and washed for destaining with a $1: 1$ ratio of $30 \mathrm{mM}$ potassium ferricyanide and $100 \mathrm{mM}$ sodium thiosulfate for $10 \mathrm{~min}$. After rinsing with water 3 times, the gels were incubated in $200 \mathrm{mM}$ ammonium bicarbonate for $20 \mathrm{~min}$, and the liquid was discarded. The gels were incubated in a solution of $50 \%$ acetonitrile in $100 \mathrm{mM}$ ammonium bicarbonate for $15 \mathrm{~min}$, and then the solution was displaced with $10 \mathrm{mM}$ dithiothreitol in $100 \mathrm{mM}$ ammonium bicarbonate. After incubation for $1 \mathrm{~h}$ at $50^{\circ} \mathrm{C}$, an equal volume of
$50 \mathrm{mM}$ iodoacetamide in $100 \mathrm{mM}$ ammonium bicarbonate was added to the gels, followed by incubation for $40 \mathrm{~min}$ at room temperature. The gels were rinsed with $50 \%$ acetonitrile in $100 \mathrm{mM}$ ammonium bicarbonate for $10 \mathrm{~min}$ twice. After drying the gels, $0.01 \mathrm{mg} / \mathrm{ml}$ trypsin in $0.01 \%$ SDS/100 mM ammonium bicarbonate was absorbed onto gels, and incubated overnight at $37^{\circ} \mathrm{C}$.

MALDI-TOF-MS analysis. Peptide extracts were dissolved in $30 \mu \mathrm{l}$ of $50 \%$ acetonitrile solution with $0.5 \%$ trifluoroacetic acid (TFA) and desalted using C18 ZipTips (Millipore, Billerica). The peptide mixtures were eluted repeatedly in $5 \mu \mathrm{l}$ of $70 \%$ acetonitrile/ $0.1 \%$ TFA. One microliter of peptide mixture was deposited onto a target disk, immediately after $1 \mu \mathrm{l}$ of $\alpha$-cyano-4-hydroxycinnamic acid matrix solution was added to the peptide samples. All the samples were analyzed using AutoFLEX (Bruker Daltonics, Billerica). External calibration was performed using a peptide calibration standard (Bruker Daltonics). Internal calibration was also performed using the autodigested peaks of trypsin. Monoisotopic peptide masses were assigned and peptides in the mass range of 1000 $3000 \mathrm{Da}$ were recorded.

Database search. Proteins were identified using Mascot (http://www.matrixscience.com) and Ms-fit (http://www.abcc. ncifcrf.gov/ucsfhtml3.2/msfit.htm) software. Probability-based MOWSE scores were calculated by comparing the search results against an estimated random match population and were reported as $-10 \times \log _{10}(P)$, where $P$ is the absolute probability. Scores greater than 68 were considered significant $(P<0.05)$.

siRNA transfection. siRNA for teneurin-2 was designed by a Takara siRNA design support system (http://www2. takara-bio.co.jp), and was synthesized by Takara. Sense (5'-UGUGACCAGUAUCUUGGAGUU-3') and antisense (5'-CUCCAAGAUACUGGUCACAUU- $3^{\prime}$ ) RNAs were annealed and used. Transfection was carried out in serumfree medium following the manufacturer's procedures using TransIT-TKO (Mirus, Madison). The optimal incubation period (2 days) until RNA extraction was determined previously.

Reverse transcription-polymerase chain reaction. DNase Itreated total RNAs extracted from the sample were used for reverse transcription (RT), and polymerase chain reaction (PCR) was performed using a primer set for teneurin-2 designed to amplify 2703-3114 bp of rat teneurin-2, sense; 5'-YTGCTGCCTCCAGTCMRCYTG-3', antisense; 5'-GGCA TAGAAGCTGTTCCACGGC- ${ }^{\prime}$. As a positive control, glyceraldehyde 3-phosphate dehydrogenese (GAPDH) mRNA was also detected using a primer set designed to amplify 547-1073 bp of rat GAPDH, sense; 5'-CCAAGGTCATCCAT GACAAC- ${ }^{\prime}$, antisense; $5^{\prime}$-TTACTCCTTGGAGGCCATGT- $3^{\prime}$. The PCR program for teneurin-2 was carried out at 40 cycles of $30 \mathrm{~s}$ at $94^{\circ} \mathrm{C}, 1 \mathrm{~min}$ at $63.5^{\circ} \mathrm{C}$, and $1 \mathrm{~min}$ at $72^{\circ} \mathrm{C}$. The program for GAPDH was carried out at 25 cycles of $30 \mathrm{~s}$ at $94^{\circ} \mathrm{C}, 1 \mathrm{~min}$ at $58^{\circ} \mathrm{C}$, and $1 \mathrm{~min}$ at $72^{\circ} \mathrm{C}$. Optimal annealing temperatures and cycle numbers for quantitative comparison were previously determined. 
Statistical analysis. Statistical comparisons were made by Student's $t$-test, or one-way analysis of variance, followed by Dunnett's post hoc test. Values of $P<0.05$ were considered significant. The means of the data are presented together with SEM.

\section{RESULTS}

\section{Effect of M1 on Neurite Extension in Cortical Neurons}

We investigated the effects of M1 on neurite extension in cultured cortical neurons. Rat cortical neurons were treated by $\mathrm{M} 1$ at day 4 . At day 14 (treated for 10 days), cells were fixed and immunostained with an antibody of phosphorylated NF-H (P-NF-H, axonal marker) or MAP2 (dendritic marker). Treatment with 0.001 and $0.01 \mu \mathrm{M}$ M1 significantly enhanced the length of phosphorylated NF-H-positive neurites compared with vehicle-treated cells (Figure 1a). In contrast, the length of MAP2-positive neurites was not increased by treatment with any doses of M1 $(0.001-10 \mu \mathrm{M})$ (Figure 1b).

\section{Phosphorylated Proteins by M1 Stimulation in Rat Cortical Neurons}

To investigate the target molecule and signal transduction of $\mathrm{M} 1$, proteins phosphorylated by M1 stimulation were identified. Rat cortical neurons were treated with $0.01 \mu \mathrm{M}$ $\mathrm{M} 1$, and after 10 and $60 \mathrm{~min}$ incubation, the reaction was stopped. Cell lysate was immunoprecipitated with antiphosphorylated tyrosine antibody. Precipitated samples were electrophoresed on SDS-PAGE and silver stained. Protein bands, which were increased by M1 stimulation compared with the control, were excised from the gel, and analyzed by MALDI-TOF-MS. In a lane of M1-treated cells, a band of approximately $300 \mathrm{kDa}$ (band 1) after 10-min stimulation, and a band of less than $160 \mathrm{kDa}$ (band 2) after 60-min stimulation were seen, which were hardly detected in the control lane (Figure 2). Mass data of the bands were researched on peptide mass databases, Mascot and MS-Fit. As a result, bands 1 and 2 were suggested to be teneurin-2 (MOWSE score: 21850) and mPar3 (MOWSE score: 371), respectively.

Teneurin-2 consists of 2765 amino acids $(306.6 \mathrm{kDa})$, and was cloned in chicks, mice, rats, and humans (Minet and Chiquet-Ehrismann, 2000). The expression pattern of teneurin-2 is predominant in the brain (Otaki and Firestein, 1999; Rubin et al, 1999; Tucker et al, 2001), and is richer in the developmental stage than in the adult period (Otaki and Firestein, 1999; Rubin et al, 1999). Previously known functions of teneurin-2 are the formation of filopodia (Rubin et al, 1999), growth cone enlargement (Rubin et al, 1999), and promoting cell-cell adhesion (Rubin et al, 2002). The putative structure of teneurin-2 is a type II transmembrane protein. In the extracellular domain, there are eight EGF-like repeats (Otaki and Firestein, 1999). Although teneurin-2 is speculated to act as a homophilic adhesive protein, we supposed another scenario in which the membrane-spanning protein acts as a signaling molecule, like growth factor receptors.

mPar3 is a $150 \mathrm{kDa}$ protein, making a complex with mPar6 and atypical protein kinase $\mathrm{C}$ (aPKC), and this complex is crucial for cell polarity. Especially in neurons, the polarized localization of the complex is important for axon specification (Shi et al, 2003). The localization of the mPar3 complex is regulated by PI3-kinase (Shi et al, 2003; Schwamborn and Püschel, 2004). Therefore, we hypothesized that PI3-kinase might be located upstream of mPar3 phosphorylation, and teneurin-2 might transduce signals through PI3-kinase.

\section{Effect of Decreased Teneurin-2 on PI3-Kinase Activity and Axonal Extension}

Rat cortical neurons were treated with siRNA for teneurin-2 at 10 or $50 \mathrm{nM}$ for 2 days. Total RNA was then extracted, and the expression level of teneurin-2 mRNA was measured by semiquantitative RT-PCR. Teneurin-2 mRNA was decreased by treatment with $10 \mathrm{nM}$ siRNA compared with control and mock transfectants (Figure 3). Although $50 \mathrm{nM}$ siRNA also reduced teneurin- 2 mRNA, this inhibition was not potent compared with $10 \mathrm{nM}$, and cell toxicity was weak.

To investigate whether M1 stimulation (treated for $1 \mathrm{~h}$ ) results in PI3-kinase activation through teneurin-2, phosphorylated Akt (P-Akt) was immunostained in neurons treated by siRNA for teneurin-2. Double immunostaining for P-Akt and P-NF-H, or P-Akt and MAP2 was carried out to distinguish PI3-kinase activity on axons or dendrites. In mock transfectants, P-Akt was distributed mainly in cell bodies when treated by the vehicle (Figure 4). However, P-Akt-positive puncta were localized in many axons $1 \mathrm{~h}$ after M1 administration. On the other hand, the localized puncta of P-Akt decreased in teneurin-2 siRNA-treated and M1-stimulated neurons. These results were quantified in Figure 5a. Significantly increased P-Akt expression in axons was induced by M1 stimulation in mock transfectants; however, P-Akt expression was not enhanced in teneurin-2-
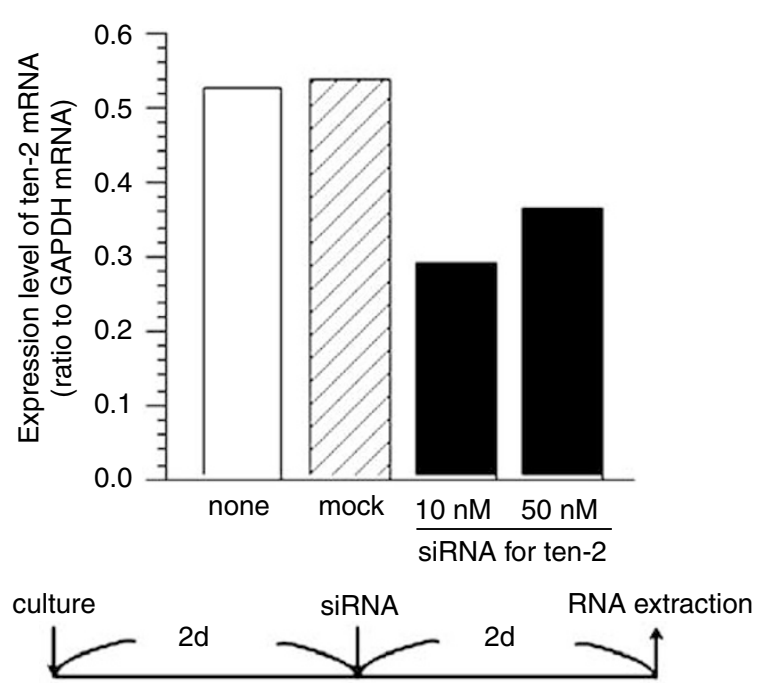

Figure 3 Effect of siRNA transfection on teneurin-2 mRNA expression. siRNA for teneurin-2 (10,50 nM) or water (mock) was transfected into rat cortical neurons at 2 days after culture. Untransfected cells (none) were also used as a control. After 2 days, total RNA was extracted, and the expression levels of teneurin-2 mRNA and GAPDH were measured by semiquantitative RT-PCR. Ratios of teneurin-2 mRNA to GAPDH mRNA were shown. 


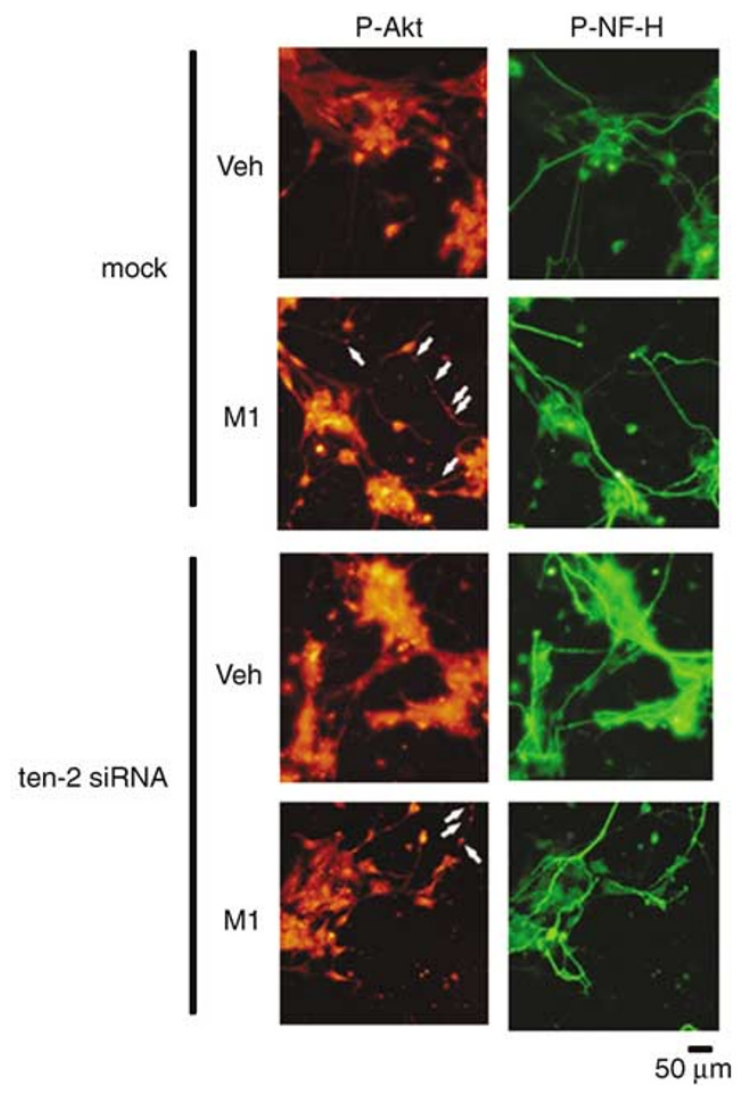

Figure 4 Effect of teneurin-2 knockdown on MI-induced PI3-kinase activation in axons. siRNA for teneurin-2 ( $10 \mathrm{nM}$ ) or water (mock) was transfected into rat cortical neurons at 3 days after culture. After 2 days, $0.01 \mu \mathrm{M} \mathrm{MI}$ or the vehicle (Veh, 0.1\% DMSO) was administered to the cells. After I h later, cells were fixed and double-immunostained for phosphorylated Akt and phosphorylated NF-H. Arrows show phosphorylated Akt-positive puncta. Scale $=50 \mu \mathrm{m}$.

deficient neurons even after M1 treatment. The length of axons was measured in those neurons (Figure 5b). Significantly increased axon length was induced by M1 stimulation in mock transfectants; however, axons were not extended in teneurin-2-deficient neurons even after M1 treatment. Double staining for P-Akt and MAP2 showed that localized P-Akt puncta were seen in M1-treated neurons that were not dendrites (Figure 6).

To confirm the involvement of PI3-kinase in M1 signal transduction, neurons were treated with PI3-kinase inhibitor, LY294002 (Figure 7). P-NF-H-positive neurites, axons, were significantly extended by M1 treatment for 4 days. When LY294002 (0.1 and $1 \mu \mathrm{M})$ was simultaneously treated with M1, axonal extension was significantly inhibited.

\section{DISCUSSION}

Treatment with M1, a metabolite of ginseng protopanaxadiol-type saponins, extended axons, but not dendrites, in rat cortical neurons (Figure 1). As described in our previous report, M1 can regenerate axons and synapses, and therefore recover memory impairment in amyloid $\beta(25-35)$ injected mouse brain (Tohda et al, 2004). In addition,

a

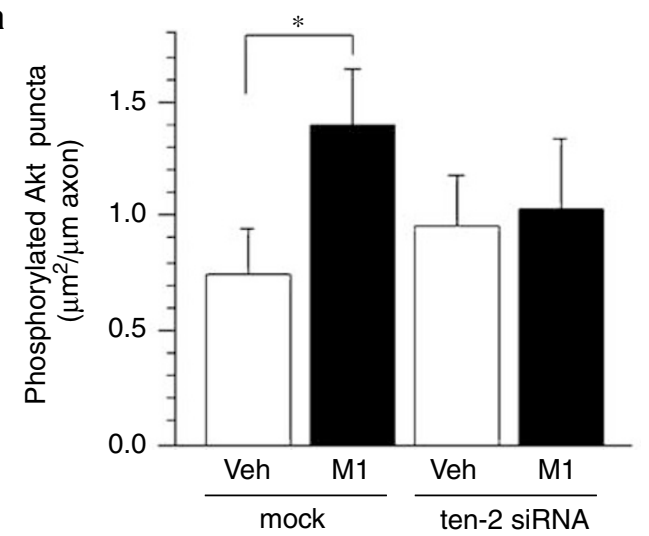

b
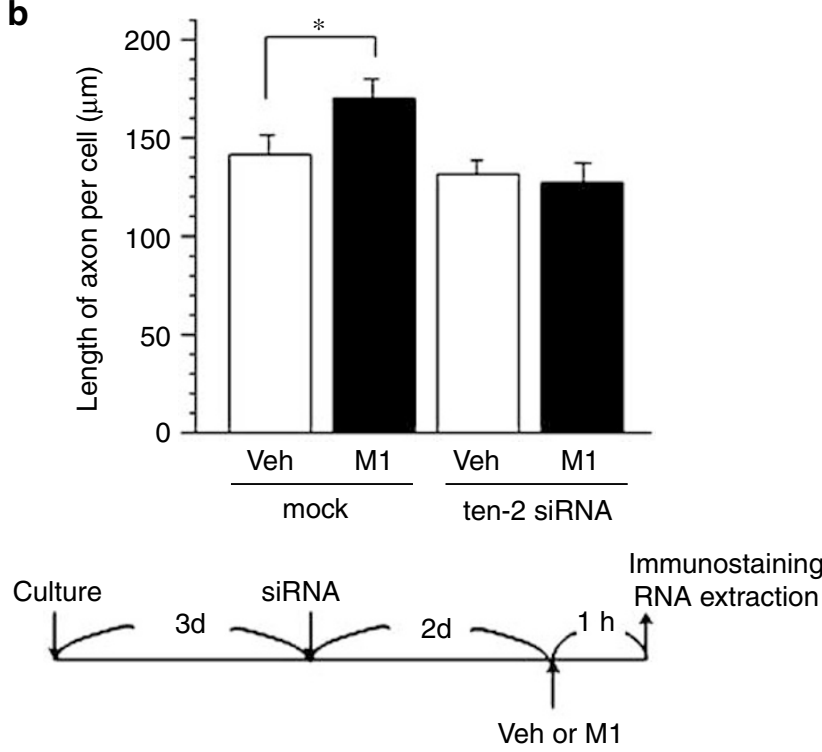

Figure 5 Effects of teneurin-2 knockdown on MI-induced PI3-kinase activation in axons, and axonal extension. (a) Quantified data of Figure 4. Areas of phosphorylated Akt-positive puncta per I $\mu \mathrm{m}$ of axon were measured. (b) Axonal lengths per neuron. The values represent the means and SEM of $7 \mid-95$ axons. $* P<0.05$.

\section{P-Akt/MAP2}

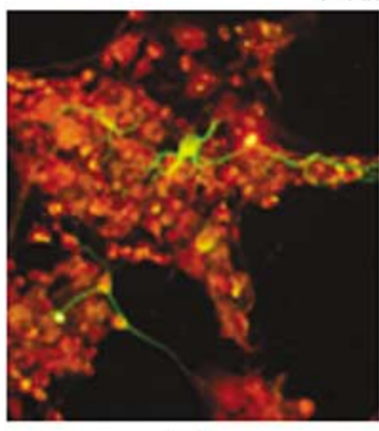

Veh

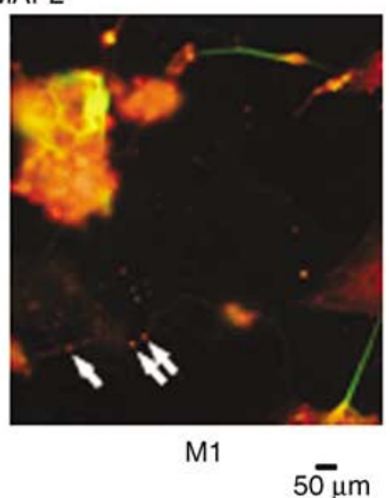

Figure 6 Effect of teneurin-2 knockdown on MI-induced PI3-kinase activation in dendrites. siRNA for teneurin-2 $(10 \mathrm{nM})$ or water (mock) was transfected into rat cortical neurons at 3 days after culture. After 2 days, $0.01 \mu \mathrm{M} \mathrm{MI}$ or the vehicle (Veh, 0.1\% DMSO) was administered to the cells. After I h, cells were fixed and double-immunostained for phosphorylated Akt (red color) and MAP2 (green color). Arrows show phosphorylated Akt-positive puncta. Scale $=50 \mu \mathrm{m}$. 


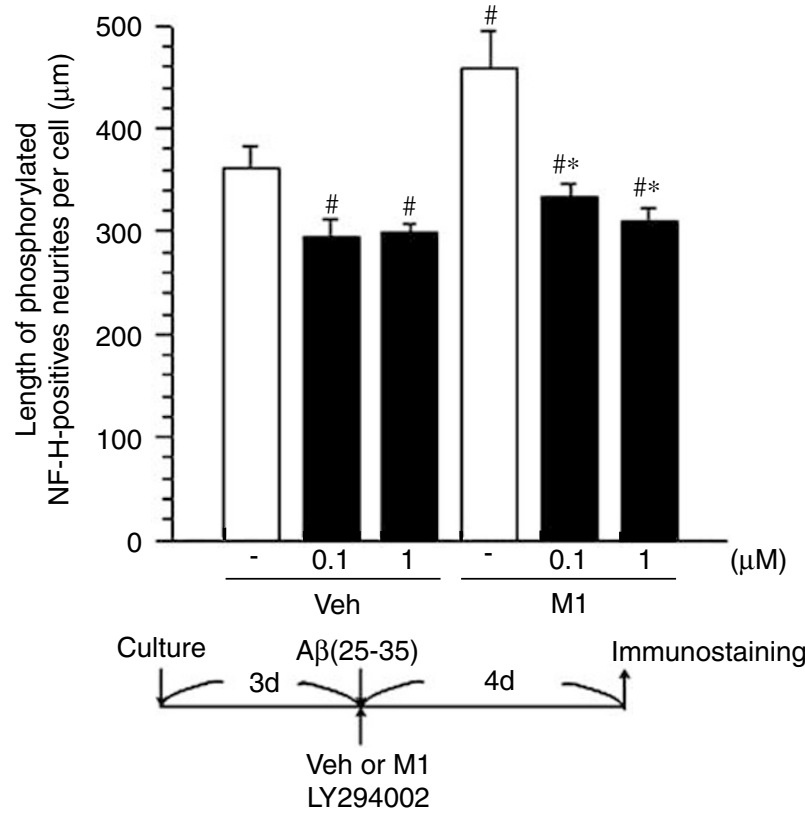

Figure 7 Effect of PI3-kinase inhibitor on $\mathrm{Ml}$-induced axonal extension. MI $(0.01 \mu \mathrm{M})$ or the vehicle (Veh, $0.1 \% \mathrm{DMSO})$ were added with $10 \mu \mathrm{M}$ $A \beta(25-35)$ to rat cortical neurons 3 days after the start of the culture period. PI3-kinase inhibitor, LY294002 was simultaneously added at 0.1 or I $\mu$ M. After 4 days, cells were fixed and immunostained for phosphorylated $\mathrm{NF}-\mathrm{H}$. The lengths of neurites positive for phosphorylated NF-H per cell were measured. Values represent the means and SEM of 23-30 neurons. ${ }^{*} P<0.05$ when compared with Veh/LY294002 (-), ${ }^{\#} P<0.05$ when compared with MI/LY294002 (-).

treatment with M1 recovers synaptic loss in amyloid $\beta(25-$ 35)-treated cultured cortical neurons (unpublished data). Although M1 was also reported to have an anticancer effect (Wakabayashi et al, 1998; Lee et al, 1999), no target molecule of M1 has been clarified. Knowing the target and signal transduction of M1 may elucidate the mechanism of axonal formation.

Most intracellular signal transductions are through phosphorylation cascades. Therefore, we had the idea that target molecules of M1 might be identified by analyzing phosphorylated proteins after M1 treatment. After stimulation with $\mathrm{M} 1(0.01 \mu \mathrm{M})$, two bands were shown as specifically phosphorylated proteins by M1 in tyrosine residue (Figure 2): teneurin-2 and mPar3. By sequence motif analysis, one intracellular tyrosine kinase phosphorylation site exist in teneurin-2. Drosophila homolog of teneurin, odz was shown to be phosphorylated on tyrosine (Levine et al, 1994). In mPar3, three putative sites exist as tyrosine kinase phosphorylation sites. Therefore, it is reasonable that teneurin-2 and mPar3 were identified as tyrosine phosphorylated proteins.

Interestingly, mPar3 is known as a key molecule for axonal specification, and upstream PI3-kinase regulates mPar3 localization in axons (Shi et al, 2003). PI3-kinase has been shown to be involved in neurite outgrowth signaling (Rodgers and Theibert, 2002), especially in axonal formation (Edström and Ekström, 2003; Ménager et al, 2004). On the other hand, teneurin-2 is a type II transmembrane protein (Otaki and Firestein, 1999), and is involved in the formation of filopodia, and growth cone enlargement
(Rubin et al, 1999). Teneurin-2 is speculated to be not only a homophilic adhesive protein, but also a molecule necessary for neurite fasciculation and/or neuron target recognition (Rubin et al, 2002). As most growth factor receptors are transmembrane proteins, we hypothesized that teneurin-2 may function like an M1 receptor.

PI3-kinase activity can be indirectly evaluated by increased P-Akt. The puncta of P-Akt in axons were significantly increased by M1 $(0.01 \mu \mathrm{M})$ stimulation for $1 \mathrm{~h}$ (Figures 4 and 5a). As shown in Figure 6, P-Akt is not distributed in dendrites. In addition, axons were extended by M1 stimulation although the enhanced length was not particularly long due to the short period of stimulation (Figure 5b). P-Akt is known to localize in axons like a dot when axons are extending (Shi et al, 2003; Schwamborn and Püschel, 2004). By siRNA treatment, teneurin-2 mRNA could be decreased in cortical neurons (Figure 3). The phosphorylation of Akt, that is, the activation of PI3-kinase, and axonal extension were not seen in teneurin-2 knockdown neurons (Figures 4 and 5), suggesting that PI3-kinase activation by M1 occurs in axons, leading to axonal extension, and that teneurin-2 is necessary for the M1 signal to activate PI3-kinase.

Many transmembrane-type receptors, such as trkA and trkB (Klesse and Parada, 1999), are coupled with PI3-kinase at the cytoplasmic domain. The localized property and function of the filopodia formation of teneurin-2 are inhibited without its cytoplasmic domain (Rubin et al, 2002), suggesting that the cytosolic domain must be critical for the signal transduction of teneurin-2. It is also shown that the intracellular domain of teneurin-2 may be released into the cytosol, and may regulate nuclear transcription factor zic-1 (Bagutti et al, 2003). Although the entire mechanism of teneurin-2 function remains unclear, teneurin-2 may have several action forms by different types of ligand stimulation. An associating site or adaptor molecule for the interaction of teneurin-2 and PI3-kinase are now under investigation. In addition, it is still unknown whether M1 binds to teneurin-2 directly, and if so, which domain of teneurin-2 is needed for M1 interaction. It is also important to study the existence of physiological ligands for teneurin-2 other than M1, and whether the M1 signal through teneurin2 activates only mPar 3 or also other molecules.

In conclusion, we have found for the first time in this study that M1 induces axonal extension through the teneurin-2-PI3-kinase cascade. Teneurin-2 is a possible novel target of axonal and synaptic regeneration.

\section{ACKNOWLEDGEMENTS}

We thank Dr Zou Kun for identifying the structure of M1. This work was supported by the Uehara Memorial Foundation.

\section{REFERENCES}

Bagutti C, Forro G, Ferralli J, Rubin B, Chiquet-Ehrismann R (2003). The intracellular domain of teneurin-2 has a nuclear function and represses zic-1-mediated transcription. J Cell Sci 116: $2957-2966$

Edström A, Ekström PA (2003). Role of phosphatidylinositol 3-kinase in neuronal survival and axonal outgrowth of 
adult mouse dorsal root ganglia explants. J Neurosci Res 74: 726-735.

Klesse LJ, Parada LF (1999). Trks: signal transduction and intracellular pathways. Microsc Res Tech 45: 210-216.

Lee SJ, Sung JH, Lee SJ, Moon CK, Lee BH (1999). Antitumor activity of a novel ginseng saponin metabolite in human pulmonary adenocarcinoma cells resistant to cisplatin. Cancer Lett 144: 39-43.

Levine A, Bashan-Ahrend A, Budai-Hadrian O, Gartenberg D, Menasherow S, Wides R (1994). Odd Oz: a novel Drosophila pair rule gene. Cell 77: 587-598.

Menager C, Arimura N, Fukata Y, Kaibuchi K (2004). PIP3 is involved in neuronal polarization and axon formation. J Neurochem 9: 109-118.

Minet AD, Chiquet-Ehrismann R (2000). Phylogenetic analysis of teneurin genes and comparison to the rearrangement hot spot elements of E. coli. Gene 257: 87-97.

Odani T, Tanizawa H, Takino Y (1983). Studies on the absorption, distribution, excretion and metabolism of ginseng saponins. III. The absorption, distribution and excretion of ginsenoside $\mathrm{Rb}_{1}$ in the rat. Chem Pharm Bull 31: 1059-1066.

Otaki JM, Firestein S (1999). Neurestin: putative transmembrane molecule implicated in neuronal development. Dev Biol 212: 165-181.

Rodgers EE, Theibert AB (2002). Functions of PI3-kinase in development of the nervous system. Int Dev Neurosci 20: 187-197.

Rubin BP, Tucker RP, Brown-Luedi M, Martin D, ChiquetEhrismann R (2002). Teneurin 2 is expressed by the neurons of the thalamofugal visual system in situ and promotes homophilic cell-cell adhesion in vitro. Development 129: 4697-4705.
Rubin BP, Tucker RP, Martin D, Chiquet-Ehrismann R (1999). Teneurins: a novel family of neuronal cell surface proteins in vertebrates, homologous to the Drosophila pair-rule gene product Ten-m. Dev Biol 216: 195-209.

Schwamborn JC, Püschel AW (2004). The sequential activity of the GTPases Rap1B and Cdc42 determines neuronal polarity. Nat Neurosci 7: 923-929.

Shi SH, Jan LY, Jan YN (2003). Hippocampal neuronal polarity specified by spatially localized mPar3/mPar6 and PI 3-kinase activity. Cell 112: 63-75.

Tawab MA, Bahr U, Karas M, Wurglics M, Schubert-Zsilavecz M (2003). Degeneration of ginsenosides in humans after oral administration. Drug Metab Dispos 31: 1065-1071.

Tohda C, Matsumoto N, Zou K, Meselhy MR, Komatsu K (2004). $\mathrm{A} \beta$ (25-35)-induced memory impairment, axonal atrophy, and synaptic loss are ameliorated by M1, A metabolite of protopanaxadiol-type saponins. Neuropsychopharmacology 29: 860-868.

Tohda C, Matsumoto N, Zou K, Meselhy RM, Komatsu K (2002). Axonal and dendritic extension by protopanaxadiol-type saponins from ginseng drugs in SK-N-SH cells. Jpn J Pharmacol 90: 254-262.

Tucker RP, Chiquet-Ehrismann R, Chevron MP, Martin D, Hall RJ, Rubin BP (2001). Teneurin-2 is expressed in tissues that regulate limb and somite pattern formation and is induced in vitro and in situ by FGF8. Dev Dyn 220: 27-39.

Wakabayashi C, Murakami K, Hasegawa H, Murata J, Saiki I (1998). An intestinal bacterial metabolite of ginseng protopanaxadiol saponins has the ability to induce apoptosis in tumor cells. Biochem Biophys Res Commun 246: 725-730. 